\title{
Ideological Traces in Political Texts: A CDA Approach towards News Representation and Translation of Iran's Nuclear Program in English and Persian Written Media
}

\author{
Mahdi Aslani (Corresponding author) \\ Department of English, East Azarbaijan Science and Research Branch, Islamic Azad University, Tabriz, Iran \\ E-mail: m.aslani64@gmail.com
}

Received: 20-12-2015

Published: 01-05-2016
Accepted: 04-03-2016

doi:10.7575/aiac.ijalel.v.5n.3p.237
Advance Access Published: March 2016

URL: http://dx.doi.org/10.7575/aiac.ijalel.v.5n.3p.237

\begin{abstract}
This study intends to discuss the concept of "rewriting" in translating political news texts, specifically the news related to Iran's nuclear program. Since the ideology of the patronage plays the main role in establishing news texts, we have adopted critical discourse analysis to uncover the role of underlying ideological insight in producing the source text (ST) and the target text (TT). Through this paper, we attempt to illustrate whether the meaning of news items are preserved within translation or they are changed to cope with the ideology of patronage.
\end{abstract}

Keywords: Translation, CDA, Rewriting, Ideology, Political Discourse, Media Representation

\section{Introduction}

\subsection{Ideology and News Discourse}

Nowadays mass media are the main source to provide people with information. However, the news media is generally considered as biased. The term media bias has been defined in several ways. In Barron's paper media bias is defined "relative to the truth." The American Society of Newspaper Editors (ASNE) found that some people believe that media bias is "favorism of a particular social or political group." Under this definition, journalists could report the truth but favor one particular political party in their selection of information to be reported (Chiang, 2007, p. 3). It is widely believed that the ideology of the news provider plays the main role in delivering the news. Thompson (1990) states that news texts have great ideological significance in contemporary societies and that the production and dissemination of news texts by mass media organizations and their consumption by audiences are key processes in the operation of ideology. The notion of ideology is also a controversial subject in Translation Studies, and it is also believed that translation as a cross cultural act can be ideologically manipulated. "Ideology plays a crucial role in news translation. Despite this, very little research has been undertaken to examine this phenomenon and the impact it has on the authenticity and the validity of news translation which carry ideological standpoints" (Malkawi, 2012, p. 16). News discourse is always filled with controversial issues depending on the different factors such as providers' beliefs or the country's cultural, religious and political affiliation. A translator rendering news items may come across news that contradicts their beliefs and views. Therefore, he/she could render the news due to their ideological standpoints. As a weapon which directs the translation, the translator's ideology has an important role in TT readers' conceptualization of the world. However, it has been undoubtedly proven by many researchers that:

A translator, as a second text producer, tends to let his beliefs and ideas intervene while producing the (TT) and make hidden directives that will change the receivers' own viewpoints. In this respect, the ideology of the translator can pervade the text produced to express his own views leaving. (Ashubbak, 2013, pp. 2-3).

\section{Literature Review}

\subsection{Cultural Turn in Translation}

It is generally believed that the development of translation theory has undergone three stages. The first stage which Gentzler (1993) calls as "traditional" or "pre-scientific" period (Gentzler, 1993, p. 182), lasted "from the very beginning of Babel tower until World War II." The translation in this period "was concerned mainly with literature, with the focus of translation theory on literary translation on the basis of literal versus free translation" (Low, 2009. p. 154). In the middle of the $20^{\text {th }}$ century and by the advent of linguistics, translation studies entered into a scientific era. In this period some scholars with linguistic background began to study translation. Jakobson, Catford and Nida are leading figures in this approach. Since translation itself is intricately related to language. The development of linguistics has greatly contributed to the study of translation. In this period the notion of equivalence was at the center of attention. However, linguistics could not explain some of the issues in relation to culture. Hence, some scholars like Bassnette and Lefevere dismiss linguistics and "they go beyond and focus on interaction between translation and culture" (Munday, 2001, p. 127). In their introduction to the collection of essays Translation, History and Culture, they emphasized that "translation has been a major shaping force in the development of world culture" (Bassnette \& Lefevere 1990, p. 12). 
As Christina Schäffner states, they concentrate on "social, cultural and communicative practices, on the cultural and ideological significance of translating and of translations, on the external politics of translation, on the relationship between translation behavior and socio-cultural factors" (Schäffner, 2004, p. 136). Therefore, it has gradually been recognized that to a great extent culture determines the translation process and the final version (Low, 2009. p. 154). Translation was understood as neither an "interpretation" nor an "imitation", but a "competition" with the original (Gentzler, 1993, p. 126). In other words since the early 1990s, we observe that Translation Studies enters into 'cultural turn'. Bassnette explains the 'cultural turn' as follows:

A way of understanding how complex manipulative textual processes take place: how a text is selected for translation, for example, what role the translator plays in that selection, what role an editor, a publisher or patron plays, what criteria determine the strategies that will be employed by the translator, how a text might be received in the target system. For a translation always takes place in a continuum, never in a void, and there are all kinds of textual and extra textual constraints upon the translator. (Bassnett \& Lefevere, 1998, p. 123)

With the advent of culture into translation studies, scholars in this field paid more attention at the relationship between discourse and ideology, two concepts related with culture. In Communication Across Cultures-Translation Theory and Contrastive Text Linguistics, Basil Hatim refers to the notion of discourse as "the attitudinally determined mode of expression," and he points out that it is "particularly privileged as a carrier of ideological meanings" (Hatim, 2000, p. 174). Indeed, "ideology appears to be one of the crucial features of discursive expression, and the analyses of ideological structures have proved useful in providing insights into the study of language and discourse" (Sertkan, 2007, p. x). In Teaching and Researching Translation, Hatim touches upon some aspects of 'the ideology of translation' which contemporary translation theorists have become concerned with (Hatim, 2001, pp. 83-84):

- the choice of words to be translated (what is valued and what is excluded)

- the power structure which controls the production and consumption of translations

- who has access to translation and who is denied access?

- what is omitted, added or altered in seeking to control the message?

\subsection{Translation as Rewriting or Manipulation}

Lefevere, one of the forerunners in shaping the cultural turn in translation studies, put forward the concept of "translation as rewriting". According to Hermans (2004), Lefevere developed his idea about systems and the place of "rewriting" in them over a period of about fifteen years and lots of his essays were collected in Translation, Rewriting, and the Manipulation of Literary Fame (Hermans, 2004, p. 126). In 1981 Lefevere introduced the concept of the "refracted text". By "refracted text" he means "texts that have been processed for a certain audience (children, for example) ", or adapted to a certain poetics or a certain ideology (Lefevere, 1981, as cited in Gentzler, 2004, p. 137). In 1982 Lefevere took the term "refraction" to mean "the adaptation of a work of literature to a different audience, with the intention of influencing the way in which that audience reads the work" (Lefevere, 1982, as cited in Hermans, 2004, p. 127). In 1984, Lefevere defined and added the concept of "patronage" to his model in order to better investigate ideological pressures (Lefevere, 1984, as cited in Gentzler, 2004, p. 137). In 1985, Refraction gave way to "rewriting". By "rewriting", Lefevere referred to any text produced on the basis of another with the intention of adapting that other text to a certain ideology or to a certain poetics and, usually, to both (Lefevere 1985, as cited in Hermans, 2004, p. 127). In Translation, Rewriting and the Manipulation of Literary Fame, Bassnett and Lefevere (199) formally present their theory "translation is a rewriting of an original text." According to them,

All rewritings, whatever their intention, reflect a certain ideology and a poetics and as such manipulate literature to function in a given society in a given way. Rewriting is manipulation, undertaken in the service of power, and in its positive aspect can help in the evolution of a literature and a society. Rewriting can introduce new concepts, new genres, new devices and the history of translation is the history also of literary innovation, of the shaping power of one culture upon another. But rewriting can also repress innovation, distort and contain, and in an age of ever increasing manipulation of all kinds, the study of the manipulation processes of literature are exemplified by translation can help us towards a greater awareness of the world in which we live (Bassnett and Lefevere, 1990, p. vii).

Therefore it is clear that "translation is not a pure, simple and transparent linguistic matter but involves factors such as power, ideology, poetics and patronage, etc" (Shuping, 2013, p.56).

Hermans (2004) states that rewriting includes translation, criticism, summary, adaptation for children, anthologizing, making into a comic strip or TV film, and so on (Hermans, 2004, p. 127). And translation is regarded by Lefevere as "the most obviously recognizable type of rewriting, and potentially the most influential because it is able to project the image of an author and/or a (series of) work (s) in another culture, lifting that author and/or those works beyond the boundaries of their culture of origin" (Lefevere, 1992, p. 9).

\subsection{Translation, Ideology and Power}

According to Lefevere (1992), translation is an activity "carried out in the service of power" (Lefevere 1992, p. vii). The power can be exerted by a person, groups of persons, a religious body, a political party, a social class, a royal court, 
publishers, and the media. One of the main constituents of power is ideology. Ideology has been defined in several ways ranging from Marxist false consciousness explanation of ideology, Althusser's (1971) ideological interpellation of a subject through the state's ideological apparatuses, Seliger's (1976) concept of a political belief system, Foucault's (1980) effect of ideological discipline on the human body, Terry Eagleton's (1991) patrons ideas or beliefs, to Van Dijk's (2006) definition of ideology as "the foundation of the social representations shared by a social group."(Van Dijk, 2006, p. 729). The concepts of power, ideology and translation are intricately interwoven that is to say translation is the product of power relations and ideological insights involved. The notion of ideology has always been in relation with translation. Regarding to translation, Mason (2010) describes ideology as follows:

Not in the commonly used sense of political doctrine but rather as the set of beliefs and values which inform an individual's or institution's view of the world and assist their interpretation of events, facts and other aspects of experience (Mason, 2010, p. 6).

As it is seen translation carries translator's point of view about the world. Therefore, translation is under the constraints of certain ideology of the patron. Bassnett (1980) argues that translated texts are so far removed from the original that they need to be considered as independent products of literature.

News media carry the ideological stand points of news media networks that produce them. The ideological insight is a critical factor in decision-making process in the translation of political discourse and as an invisible force it affects the translation product (Malkawi, 2012, p. 14). Therefore, this paper attempts to reveal the role of ideology as a discursive power in translating news media of political discourse. Hence, we are intended to examine the role of ideology in manipulating the translation product of news media; thus, we have utilized Critical Discourse Analysis.

\subsection{What is $C D A$ ?}

Critical discourse analysis (CDA) is a rapidly developing area of language study. It regards discourse as "a form as social practice" (Fairclough \& Wodak, 1997, p.258), and takes consideration of the context of language use to be crucial to discourse (Wodak, 2001). It takes particular interest in the relation between language and power. CDA is actually a holistic approach which binds together elements from many other disciplines (Kress 1992, p. 92). In fact, Critical Discourse Analysis is not a homogenous model; it is a sort of discourse that does not consider language use free from ideological perspectives. "The term CDA is used nowadays to refer more specifically to the critical linguistic approach of scholars who find the larger discursive unit of text to be the basic unit of communication" (Wodak, 2001, p.6). It is, generally speaking, "a study of the relations between discourse, power, dominance, social inequality and the position of the discourse analyst in such social relationships" (Van Djik, 1993, p. 283).

It should be mentioned that CDA connects a relationship between text and social context and explores the links between textual structures and their function in interaction within the society; a complex multi-level analysis between social context and textual structures especially when it comes to creating and maintaining differences in power relations. The relatedness of the complex mechanism of discursive practice and their social function is frequently and willingly left opaque, especially when the need occurs to create and maintain differences in power relations (Horváth p.45-46). One of the objectives of CDA is to create a framework for decreasing this said opacity. Fairclough (1993) in his definition perceives CDA as:

discourse analysis which aims to systematically explore often opaque relationships of causality and determination between (a) discursive practice, events and texts, and (b) wider social and cultural structures, relations and processes; to investigate how such practices, events and texts arise out of and are ideologically shaped by relations of power and struggles over power; and to explore how the opacity of these relationships between discourse and society is itself a factor securing power and hegemony (Fairclough, 1993, p. 135).

It should be noted that the relationship is "bi-directional". Not only the language use is affected by its groundedness within certain frame of cultural or social practice, but also the use of language influences and shapes the social and cultural context it finds itself in"(Horváth, 2009, p.46). The one element of CDA by which it is differentiated from other forms of discourse analysis lies in its attribute of 'critical'. According to Rashidi \& Souzandehfar (2010):

While Discourse Analysis focuses on the relationship between language forms and a limited sense of context and tends to be oriented to a narrow understanding of the larger social, cultural and ideological forces that influence our lives, CDA goes much further toward addressing the ideological dimensions of discourse (p. 56).

Fairclough (1992) believes that "critical implies showing connections and causes which are hidden; it also implies intervention, for example providing resources for those who may be disadvantaged through change" Fairclough (1992, p. 9).

\subsection{Different Approaches to $C D A$}

Van Dijk (2007) classifies CDA to four mainstream approaches as follows: 
- Critical Linguistics developed by Fowler et. al., (1979) and Kress and Hodge (1979).

- Sociocultural approach introduced by Fairclough (1989, 1992, 1995a).

- Discourse-Historical approach presented by Wodak and her colleagues in The Vienna School of Discourse Analysis (Wodak et. al., 1999).

- $\quad$ Socio cognitive approach proposed by Van Dijk (1998, 2002).

\subsubsection{Fowler (Critical Linguistics)}

The work of Fowler et al. (1979) has been cited as the earliest and the starting point of Critical Linguistics (CL). It is one of the most influential linguistically-oriented critical approaches to discourse analysis (Rashidi \& Souzandehfar, 2010, p. 57). According to Fowler(1991), "critical linguistics simply means an enquiry into the relations between signs, meanings and the social and historical conditions which govern the semiotic structure of discourse, using a particular kind of linguistic analysis" (Fowler, 1991, p. 90). It utilizes Halliday's Systemic-Functional Linguistic (SFL) as an analytic methodology. Hodge and Kress (1993) provided some transformations such as "transitivity, nominalization, negative incorporation and agentless passive. They argued that drawing on these transformations, one can reveal intentions subtly disguised in complex structures, concealments and deceptions incorporated in transformationally derived sentences" (Hodge and Kress 1993, as cited in Rashidi \& Souzandehfar, 2010, p.57).

\subsubsection{Fairclough (Sociocultural Model)}

Fairclough (1989) called his approach to language and discourse Critical Language Study. He described the objective of this approach as "a contribution to the general raising of consciousness of exploitative social relations, through focusing upon language" (Fairclough, 1989, p. 4-5). This aim in particular "remains in his later work that further develops his approach so that it is now one of the most comprehensive frameworks of CDA" (Chouliaraki and Fairclough, 1999, as cited in Sheyholislami, 2001, p.6).

CDA, for Chouliaraki and Fairclough (1999), brings social science and linguistics together within a single theoretical and analytical framework, setting up a dialogue between them (Chouliaraki and Fairclough, 1999, p.6). Fairclough's model of CDA provides "a more accessible method of doing CDA than alternative theoretical approaches" (Richardson, 2007, p. 37). In this approach of CDA, there are three analytical focuses in analyzing any communicative event (interaction). They are "text (e.g. a news report), discourse practice (e.g. the process of production and consumption), and sociocultural practice (e.g. social and cultural structures which give rise to the communicative event)" (Fairclough, 1995b, Chouliaraki and Fairclough, 1999, p. 113, as cited in Sheyholislami, 2001, p. 6).

\subsubsection{Fairclough's Framework for Analyzing Communicative Event}

\section{A. Text:}

The first term that is crucial in an understanding of CDA is text, which in Fairclough's words refers to "the written or spoken language produced in a discursive event". Text Analysis is the first dimension of Fairclough's three-part model. It involves linguistic analysis in terms of vocabulary, grammar, semantics, the sound system, and cohesion organization above the sentence level (Fairclough, 1993, p. 138, Fairclough, 1995b, p. 57). Following SFL, Fairclough (1995b) also views text from a multifunctional perspective that is any sentence in a text is analyzable in terms of what he calls as representations, relations, and identitie (Fairclough, 1995b).

- Particular representations and recontextualizations of social practice (ideational function) -- perhaps carrying particular ideologies.

- Particular constructions of writer and reader identities (for example, in terms of what is highlighted -whether status and role aspects of identity, or individual and personality aspects of identity).

- A particular construction of the relationship between writer and reader (as, for instance, formal or informal, close or distant) (Fairclough, 1995b, p. 58).

According to Fairclough (1995b), linguistic analysis includes "representations, categories of participant, and constructions of participant identity or participant relations"(p. 58).

\section{B. Discourse Practice:}

According to Fairclough (1995b), this dimension has two facets: institutional process (e.g. editorial procedures), and discourse processes (changes the text go through in production and consumption) (Fairclough, 1995, pp. 58-60, as cited in Sheyholislami, 2001, p.7). For Fairclough, "discourse practice straddles the division between society and culture on the one hand, and discourse, language and text on the other" (Fairclough, 1995b, pp. 60), as shown in the following Figure. 
Text production

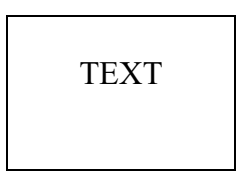

Text consumption

SOCIOCULTURAL PRACTICES

Figure 1. Critical discourse analysis of a communicative event (Fairclough, 1995b, p. 59)

\section{Sociocultural Practice:}

For Fairclough (1995b), analysis in this dimension pertains to three aspects of the "sociocultural context of a communicative event: economic (i.e. economy of the media), political (i.e. power and ideology of the media), and cultural (i.e. issues of values)" (Fairclough, 1995b, p. 62, as cited in Sheyholislami, 2001, p. 9).

\subsubsection{Wodak (Discourse Historical Model)}

Wodak who was advocated by Vienna School in critical discourse analysis bases her model on sociolinguistics in the Bernsteinian tradition. According to Wodak (1996):

Discourse Sociolinguistics... is a sociolinguistics which not only is explicitly dedicated to the study of the text in context, but also accords both factors equal importance. It is an approach capable of identifying and describing the underlying mechanisms that contribute to those disorders in discourse which are embedded in a particular context - whether they be in the structure and function of the media, or in institutions such as a hospital or a school — and inevitably affect communication (Wodak, 1996, p. 3).

In this approach, the connection between fields of "action, genres, discourses and texts is described and modeled and the context is understood mainly historically" (Wang, 2006, p. 68). In the discourse historical method approach (similar to Fairclough's), it is believed that language "manifests social processes and interaction" and "constitutes" those processes as well. According to Wodak \& Ludwig (1999), viewing language this way entails three things at least. First, discourse "always involves power and ideologies. No interaction exists where power relations do not prevail and where values and norms do not have a relevant role". Second, "discourse ... is always historical, that is, it is connected synchronically and diachronically with other communicative events which are happening at the same time or which have happened before". Third, the discourse-historical approach is interpretive. They also believe that "the readers and listeners, depending on their background knowledge and information and their position, might have different interpretations of the same communicative event". Therefore, they assert that "the right interpretation does not exist (Wodak \& Ludwig, 1999, p. 12-13).

\subsubsection{Van Dijk (Socio-cognitive Model)}

Van Dijk is one of the leading figures in CDA; his works are mainly concerned with prejudice and racism in media discourse. For Van Dijk (1988), "discourse is not simply an isolated textual or dialogic structure rather it is a complex communicative event that also embodies a social context, featuring participants (and their properties) as well as production and reception processes" (Van Dijk, 1988, p. 2, as cited in Sheyholislami, 2001, p. 3).

According to Van Dijk (1988), "production processes" is concerned with journalistic and institutional practices of newsmaking and the economic and social practices. As he states they do not participate in the creation of media discourse rather they are related to the structures of media discourse, and the "reception processes" of analysis consists of "memorization and reproduction" of news information (Van Dijk, 1988 p. 2). What Van Dijk's analysis of media (1988, 1991, 1993) attempts to demonstrate is:

The relationships between the three levels of news text production (structure, production and comprehension processes) and their relationship with the wider social context they are embedded within. In order to identify such relationships, van Dijk's analysis takes place at two levels: microstructure and macrostructure (Van Dijk, 1988, 1991, 1993, as cited in Sheyholislami, 2001, p. 3). 
The microstructure level includes the analysis on the semantic relations between propositions, syntactic, lexical elements and so Van Dijk's analysis of news report mainly concerns with macrostructure level which argues about power relation, such as inequality and dominance in the topic structure of the news stories and their overall schema (1988). For Van Dijk (1995) the approach to CDA is socio cognitive. According to Van Dijk, social cognition is "the system of mental representations and processes of group members. " In this sense, for van Dijk, "ideologies ... are the overall, abstract mental systems that organize ... socially shared attitudes". Thus, ideologies indirectly influence the personal cognition of group members in their act of comprehension of discourse among other actions and interactions. He calls the mental representations as "models". For him, "models control how people act, speak or write, or how they understand the social practices of others". According to van Dijk, mental representations "are often articulated along $U s$ versus Them dimensions, in which speakers of one group will generally tend to present themselves or their own group in positive terms, and other groups in negative terms" (Van Dijk, 1995, pp. 2-22). He states that in order to clarify such an ideological dichotomy in discourse we need to analyze discourse in the following way:

a. Examining the context of the discourse: historical, political or social background of a conflict and its main participants

b. Analyzing groups, power relations and conflicts involved

c. Identifying positive and negative opinions about Us versus Them

d. Making explicit the presupposed and the implied

e. Examining all formal structure: lexical choice and syntactic structure, in a way that helps to (de)emphasize polarized group opinions. (Van Dijk, 1998b, pp. 61-63)

\section{Methodology}

\subsection{Overview}

Iran's nuclear program began in 1950s with the assistance of the United States. But, after Iran's 1979 Revolution, most of International cooperations on the program were cut off. In the 1990's and after the Iran-Iraq war, Iran began pursuing its nuclear program. In 2003, the United States offered full transparency of Iran's nuclear program. France, Germany and the United Kingdom and later Russia and China followed the U.S. and claimed that Iran should answer some questions about its nuclear program. Since then Iran, the IAEA and the five countries have made numerous attempts to negotiate a settlement to the dispute.

Iran's nuclear program is one of today's controversial topics. Therefore, news media appropriate a significant part for that. The way the news media cover Iran's nuclear program is important in public understanding. Since news media deliver the news in compliance with the ideological insights of their institutions, the readers and listeners of the news turn into the biased form of the news. Hence, people in all parts of the world encounter with different interpretations from the same news. Therefore, they will also have different interpretations. As Wodak \& Ludwig (1999) assert "the right interpretation does not exist; in other words the interpretations can be more or less plausible but not true" (Wodak \& Ludwig, 1999, pp. 12,13), and such interpretations are construction of reality as the news media networks find (Derwish, 2006, p. 54), and they try "to persuade the audience that this interpretation is rational and appropriate one" (Kieran, 1998, p. 27). Regarding to translation, we can say that the translators translate the news based on the ideological standpoints of their favorite news agencies or political parties. In fact, they transfer the ideas of their agencies or parties within the translations. Therefore, the translation will be also ideologically biased.

\subsection{Materials for Analysis and Procedure}

The data selected to be analyzed in this study are from some of the world's high-circulated newspapers and well-known websites. Regarding the English part of the study, and in relation to newspaper section, we fulfilled the research on The Washington Post and The Financial Times, and on the website section, we went through The Associated Press. Considering the Persian part of the study, we found all the translations on specific websites, namely DiplomaciyeIrani, Isna, Tabnak and Fars. The papers and the websites were all randomly selected from a time period of 8 April through 21 November 2013. The method for collecting the data included a simple electronic search on the net. The English news texts and their Persian translations were compared on the basis of Critical Discourse Analysis in order to uncover the impact of translator's ideological insights based on his/her respective news agency or political party.

Here we should mention that the news excerpts in this paper are the exact copies of what the given newspapers or websites have issued, so we neither accept these news items nor we reject what is being said, i.e. we makes no attempt to impose which side is correct.

\section{Data Analysis and Discussion}

The news excerpts were largely analyzed from lexicalization lens. We also borrowed Fairclough's (1995b) intertextual analysis.

\section{ST: Sample 1 - The Washington Post (April 8, 2013)}

The latest round of negotiations on Iran's nuclear program was by all accounts a disappointment. Tehran's negotiators did not spell out a full response to a proposal by the United States and five partners, for limiting its enrichment of uranium, and what they did say revealed a wide gulf between the two sides. In essence, the international coalition is offering Iran a partial lifting of sanctions in exchange for a freeze on the production of medium-enriched uranium, while Iran wants a complete lifting of sanctions in exchange for token steps that would leave its nuclear work unfettered. 


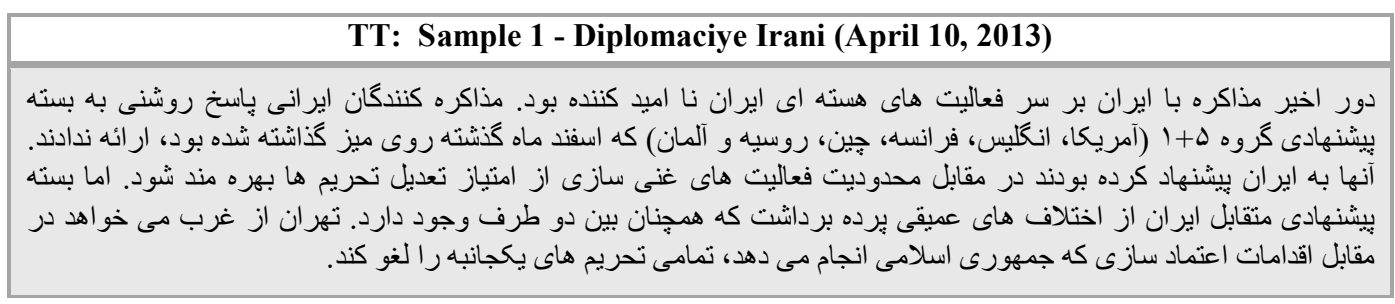

Back-Translation of TT by the Researcher

The latest round of negotiations on Iran's nuclear program was a disappointment. Iran's negotiators did not spell out a full response to the proposal of 5+1(America, England, France, China, Russia and Germany) put forward in the last Esfand (March). They had suggested that for limiting its enrichment of uranium, they will be offered a partial lifting of sanctions. But, Iran's proposal revealed a wide gulf between the two sides. Tehran wants a complete lifting of unilateral sanctions in exchange for confidence-building measures that Islamic Republic of Iran takes.

\section{Discussion of Sample 1}

As it is seen, the ST paragraph is an informative body of the latest round of negotiations on Iran's nuclear program and it is intended to foreground that these negotiations, like the previous ones, did not lead to any clear results, while the translation implies that the negotiators on Iran's nuclear program do not accept the steps taken by Iran, i.e., they are forcing Iran to obey them.

Lexically looking, by utilizing the noun phrase, the United States and five partners, the news writer illustrates that the U.S. is the leading power which encourages the other five countries to follow them; however, the translator attempts to background the role of the U.S. as a leading power in the translation by focusing on $5+1$ as an equivalence. The TT also adds the phrase "كه اسفند ماه كنشته to the translation, which shows that the translator is intended to use "Constitutive Intertextuality" in order to foreground that the negotiations of Al-ma-Ati the 2 did not end in any specific results (Fairclough, 1392, p. 85).

Another important point to be analyzed lexically is the choice of the phrase international coalition. Using this term, the ST writer intends to introduce United States and the five partners as the representatives of the whole world.

Selecting the pronoun "آنها", meaning "they", for "international coalition" in the target text, the translator attempts to hide the aim of the original text and he/she is intended to represent $5+1$ as the only opposites of Iran's nuclear activities.

The final point to be mentioned is the metaphoric use of token steps in the original text. Through this process, the news writer is attempting to make his/her audience believe that the steps taken by Iran are not sufficient to persuade the United States and five partners to lift the sanctions. Turning to the target text we find that the translator has preferred to use"اقدامات اعتمادساز" for token steps. The reason is that the Persian news agency is intended to make his/her audience believe that Iran has met its commitments; moreover, it implies that the sanctions imposed on Iran are not legitimate.

\section{ST: Sample 2 - Financial Times (April 11, 2013)}

Iran has indicated that it is willing to negotiate over the 20 percent enrichment but needs to see some of the sanctions that are crippling the economy on banking and oil-peeled off.

\section{TT: Sample 2 - Isna (April 13, 2013)}

$$
\begin{aligned}
& \text { ايران اعلام كرده است كه مايل است در باره غنى سازى } 20 \text { درصدى اور انيم كفت و كو كند ولى قبل از آن برخى تحريم هايى كه } \\
& \text { عليه اقتصاد ايران اعمال شده است بايد برداشته شود الشي }
\end{aligned}
$$

\section{Back-Translation of TT by the Researcher}

Iran has indicated that it is willing to negotiate over the 20 percent enrichment but some of the sanctions imposed against their economy should be peeled off.

\section{Discussion of Sample 2}

Despite the fact that the original text informs the readers of Iran's willingness to negotiate over 20 percent enrichment of uranium, it implies that the sanctions imposed on this country against their nuclear activities have put the economy of the country into trouble. Wearing the lens of intertextual analysis, it gets clear that the ST is intended to clarify that by the sanctions imposed on Iran's banking system and their oil industry, it seems that western countries have succeeded in making Iranians participate in the negotiations. 
Turning to the target text, it is observed that the translation is biased. In other words, the news agency has attempted to elaborate the reason for why Iran has accepted to participate in the negotiations is that western countries have asked them to participate.

Lexically looking, the choice of the verb indicate in the original text presupposes that Iran has changed its behavior and they have withdrew back from the position they had before, but the translator has altered it with an informative verb. By the choice of "اعلام كرده است", the translator tries to illustrate that the participation of Iran in the negotiations is due to the request of western countries.

\section{ST: Sample 3 - Associate Press (April 21, 2013)}

Hagel said international penalties are taking a heavy toll on Iran, though he said no one can be sure that economic coercion will compel Iran to change course.

\begin{tabular}{|c|}
\hline TT: Sample 3 - Fars (April 21, 2013) \\
\hline 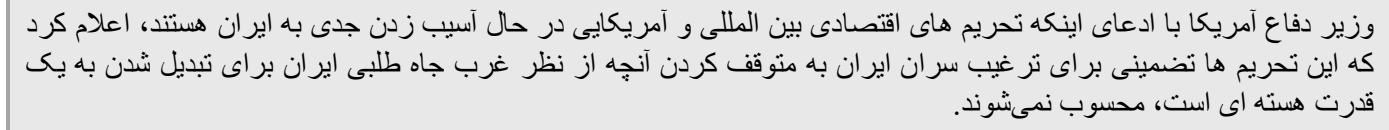 \\
\hline
\end{tabular}

\section{Back-Translation of TT by the Researcher}

US Defense minister claimed that international and American economic sanctions are taking a heavy toll on Iran, and he said no one can be sure that the sanctions will compel Iranian officials to stop what West calls Iran's ambitiousness to become a nuclear power.

\section{Discussion of Sample 3}

Scrutinizing the original text and the translation critically, it gets clear that the translation is somehow biased. As it is seen, the source text claims that Iran is approaching the zone of danger due to the sanctions which have been imposed on the country. It also presupposes that the news writer is hesitant whether or not Iran will change its nuclear course they have taken. In comparison with source text, the translator on the one hand transfers the source text content and declares that the tough sanctions imposed on the country are damaging Iran's economy. Meanwhile, he/she states that Iran's nuclear activities are legitimate.

Lexically looking, by the choice of "وزير دفاع امريكا" for Hagel the translator attempts to foreground that the role of the US in imposing sanctions on Iran's economy is more than other countries.

It is also observed that by utilizing international penalties the ST writer attempts to persuade his/her audience that Iran's nuclear activities are against international laws though international community has adapted some penalties to prevent them from continuing their plan. Using "تحريم هاى اقتصادى بين المللى و آمريكايى for international penalties in the target text, the translator is intended to reveal coercive power of the United States over other countries on this specific case.

\begin{tabular}{|c|}
\hline ST: Sample 4 - The Washington Post (November 21, 2013) \\
\hline $\begin{array}{l}\text { Iran nuclear talks entered a delicate phase Thursday as negotiators tried to fine-tune a draft agreement } \\
\text { that would limit Tehran's atomic program in return for easing some sanctions. }\end{array}$ \\
\hline TT: Sample 4 - Tabnak ( November 22, 2013) \\
\hline 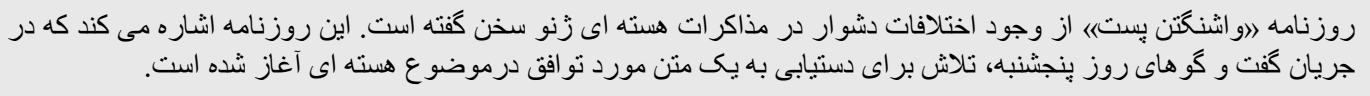 \\
\hline Back-Translation of TT by the Researcher \\
\hline $\begin{array}{l}\text { Washington Post said Iran nuclear talks in Geneva entered a delicate phase Thursday as negotiators } \\
\text { tried to reach a draft agreement on Iran's nuclear program. }\end{array}$ \\
\hline
\end{tabular}

\section{Discussion of Sample 4}

Considering the two texts comparatively we find that the two texts are differently rendered. The source text is an informative body talking about Iran's nuclear program. It implies that it is of prime importance because the negotiators are trying to reach an agreement over such a long-term issue. 
Through intertextuality, we observe that the news agency issues the conditions western countries have made in order to lift the sanctions if Iran implements his commitments. In other words, the editorial board of the American newspaper tries to make a good image from $5+1$ in the eye of the reader. Considering the translation on the other hand, we observe that the target news agency delivers the ST in a different way. To put in another way, it is biased and it has transferred only the delicacy of the negotiations. This leaves the readers in a sense of disappointment over the way of diplomacy.

Reading the target text critically, it gets clear that the Persian news agency attempts to persuade their audience that the western newspaper is against the probable agreement by mentioning emphatically to its name in the reportage, namely by eliminating some parts of the ST in TT the translator attempts to make a bad picture from western news agency in the eye of her/his reader.

\section{Conclusion}

The study showed that the underlying reasons behind ideological manipulation of the news texts are twofold. Firstly, news accounts are far from being "pure" and "impartial" reflections of "reality" and "facts." Since "news organizations are socially and politically situated, news items are inevitably produced from certain perspectives, especially from news organizations' own distinct ideologies, be they social, cultural or political." Therefore, "the news organizations' ideologies play a rather significant role in the production of news items." Secondly, the issue of ideology "continues to occupy a prominent place in translation studies" (Fowler, 1991, p. 10, as cited in Chen, 2009, p. 207). As Fawcett (1998) puts it, "through the centuries, individuals and institutions applied their particular beliefs to the production of certain effects in translation" (Fawcett, 1998, p. 107). Likewise, Schaffner (2003) indicates that "any translation is ideological since the choice of a source text and the use to which the subsequent target text is put is determined by the interests, aims, and objectives of social agent" (p. 23). Thus, Considering Lefevere's (1992) patronage, the four samples related to Iran Nuclear Program clarified western and Iranian news media's differing approaches. Put in another way, western media try to demonstrate Iran's nuclear activities illegitimate and against international laws while Iranian news media state that what they are doing is legitimate.

\section{References}

Ashubbak, I. K. (2013). The Impact of Ideology on Rendering News Items among Arab Translators. (Master's thesis, Middle East University).

Althusser, L. (1971). Lenin and philosophy and other essays. Trans. Ben Brewster. New York: Monthly Review Press.

Bassnett, S. (1980). Translation Studies, London: Routledge.

Bassnett, S., \& Lefevere, A. (Eds.). (1990). Translation, History and Culture. Cassell: London.

Bassnett, S., \& Lefevere, A. (1998). Constructing Cultures. Essays on Literary Translations. Clevendon: Multi Lingual Matters.

Chiang, C. F. (2007). Sources of Media Bias. Retrieved 15 January, 2012, Available online at: http:// homepage.ntu.edu.tw/-chungfang/Bias.pdf.

Chouliaraki, L., \& Fairclough, N. (1999). Discourse in late modernity. Rethinking Critical Discourse Analysis.

Edinburgh: Edinburgh University Press.

Eagleton, T. (1991). Ideology: An introduction. New York: Verso.

Fairclough, N. (1989). Language and Power. London: Longman

Fairclough, N. (1992). Discourse and social change. Oxford: Polity Press

Fairclough, N. (1995a). Critical Discourse Analysis: The Critical Study of Language. London: Longman.

Fairclough, N. (1995b). Media Discourse. London: Edward Arnold.

Fairclough, N., \& Wodak, R. (1997). Critical Discourse Analysis.Teun A. van Dijk, (ed.), Discourse as Social Interaction, 2, 258-84. London: Sage.

Foucault, M (1980). Power/Knowledge, selected interviews and other writings 1972-1977. Colin Gordon, Leo Marshall, John Mepham and Kate Soper (Trans.). New York: Pantheon Books.

Fowler, R., Hodge, B., Kress, G., \& Trew, T. (1979).Language \& control. London: Routledge\&Kegan Paul.

Fowler, R. (1991). Critical linguistics. In K. Halmkjaer, (Ed.), the linguistic encyclopedia (pp. 89-93). London/New York: Routledge.

Gentzler, E. (1993). Contemporary Translation Theories. New York: Routledge.

Hatim, B. (2001). Teaching and Researching Translation. Pearson Education Limited: Harlow, UK and New York.

Hernans, T. (2004).Translation in Systems. Descriptive and System-oriented Approaches Explained. Shanghai: Shanghai Foreign Language Education Press.

Horváth, J. (2009). Critical discourse analysis of Obamaee s political discourse. In Language, literature and culture in a changing transatlantic world, International conference proceedings. Presov: University of Presov (pp. 45-56).

Kress, G., \& Hodge, B. (1979/1993). Language as ideology. London: Routledge. 
Lefevere, A. (1992). Translation. Rewriting and the Manipulation of Literary Fame. London/New York: Routledge.

Lou, W. (2009). Cultural Constraints on Literary Translation. Asian Social Science, 5(10), p154.

Malkawi, R. (2012). The Ideological Stamp: Translation of Political Discourse in News Media. Whitescope Publishers.

Munday, J. (2001). Introducing Translation Studies: Theories and Applications. London and New York: Routledge.

Rashidi, N., \& Souzandehfar, M. (2010). A critical discourse analysis of the debates between republicans and democrats over the continuation of war in Iraq. Journal of Linguistics and Intercultural Education, 3, 55-82.

Richardson, J. (2007). Analyzing newspapers: an approach from critical discourse analysis. Basingstoke: Palgrave.

Schäffner, C. (2004). Political discourse analysis from the point of view of translation studies. Journal of Language and Politics, 3(1), 117-150.

Seliger, M (1976). Ideology and politics. London: George Allen \& Unwin

Sheyholislami, J. (2001). Critical discourse analysis. Retrieved March10, 2009 from http://www.server.carleton. .ca/

Shuping, R. (2013). Translation as Rewriting.International Journal of Humanities and Social Science, 3(18),56-59.

Thompson, J. B. (1990).Ideology and Modern Culture.Cambridge: Policy Press.

Van Dijk, T. A. (1993).Principles of Discourse Analysis.Discourse\& Society, 4(2), 149-283.

Van Dijk, T.A. (2002). Ideology: political discourse and cognition. In P. Chilton, \& Ch. Schaffner (Eds.), Politics as text and talk (pp. 33-57). Amsterdam: Benjamins

Van Dijk, T. A. (2004). Politics, ideology and discourse. Encyclopedia of language and linguistics, 1-32.

Van Dijk, T.A. (2007). Critical Discourse Analysis. Chapter One. Retrieved February 20, 2008 from http://www.hartcda.org.uk/sitebuildercontent/sitebuilderfiles/chapterone.pdf.

Wang, W. (2006).Newspaper commentaries on terrorism in China and Australia: A contrastive genre study. (Doctoral dissertation, The University of Sydney).

Wodak, R. (1996). Orders of Discourse (pp.1-21). New York: Addison Wesley Longman.

Wodak, R., de Cillia, R., Reisigl, M. \& Liebhart, K. (1999). The discursive construction of national identity. Edinburgh: University Press.

Wodak, R., \& Ludwig, C. (1999).Challenges in a changing world: Issues in Critical Discourse Analysis. Vienna: Passagenverlag.

Wodak, R. (2001). The discourse-historical approach. In R. Wodak \& M. Meyer (Eds.), Methods of critical discourse analysis. London: Sage Publications. 